\title{
A Capitalist World? Mapping the Limits of Market-Ism
}

\section{Colin C. Williams ${ }^{1}$}

Do we really live in a world where capitalism has penetrated every nook and cranny of daily life and stretched its tentacles ever wider across the globe? And is there really no alternative to capitalism? This paper evaluates critically whether capitalism is as victorious, colonizing and all-powerful as commonly assumed. By allowing market-ism to colonize our imaginations, the economic plurality that characterizes economies is shown to have become hidden from view and the future closed off. By putting capitalism in its place, the argument is that it is not only possible but also realistic to imagine and enact alternative futures beyond capitalism and the first step is to realise that the 'other' (non-capitalist) economy is not some marginal backwater but at the core of working life. [Article copies available for a fee from The Transformative Studies Institute. E-mail address: journal@transformativestudies.org Website: http://www.transformativestudies.org (C2009 by The Transformative Studies Institute. All rights reserved.]

KEYWORDS: Capitalism, Commodification, Marketization, Commercialization, Economic Development, Work Organization, Binary Hierarchy.

The idea that we live in a 'capitalist' society organized around the systematic pursuit of profit in the marketplace is something commonly as-

\footnotetext{
${ }^{1}$ Colin C. Williams is Professor of Public Policy in the School of Management at the University of Sheffield in the United Kingdom. His books include The Hidden Enterprise Culture (2008, Edward Elgar), Re-thinking the Future of Work (2007, Palgrave-

Macmillan) and Cash-in-Hand Work (2004, Palgrave-Macmillan). His interests are in rereading the future of work and trajectories of economic development in order to open up the future to alternative possibilities. Address correspondence to: Colin C. Williams, Professor of Public Policy, School of Management, University of Sheffield, 9 Mappin Street, Sheffield, United Kingdom S1 4DT; tel: +44 114222 3476; e-mail: C.C.Williams@sheffield.ac.uk.
} 